\title{
MICHEL FOUCAULT: PARRHESIA (TRUTH-TELLING) DAN CARE OF THE SELF
}

\author{
KONRAD KebUnG*
}

\begin{abstract}
Abstrak: Paper ini berbicara mengenai parrhesia, salah satu dari sekian banyak istilah teknis utama dari Michel Foucault. Parrhesia merupakan seminar terakhir yang didiskusikan Foucault di Universitas Calofornia di Berkeley, USA, di bawah judul: 'Discourse on Truth: The Problematization of Parrhesia.' Seri seminar ini dan seksualitas sebagaimana didiskusikan dalam History of Sexuality vol. 2 dan 3, berikut semua bahan kuliah dan interviu selama dua tahun terakhir sebelum kematiannya, dilihat sebagai puncak dari tiga jurus berpikir Foucault, terutama dalam hal ini jurus subyektivitas dan etika. Di sini terlihat, bagaimana manusia menyadari diri sebagai subjek bagi dirinya sendiri atau menjadi subjek etika. Ini berarti bahwa individu, berdasarkan kebebasan dan kematangannya, secara praktis mampu berhubungan dengan dirinya sendiri (rapport a soi). Dengan itu, ia dapat disebut sebagai parrhesiast, yang tidak hanya menyampaikan kebenaran kepada orang lain, tetapi juga mampu menyampaikan kebenaran kepada dirinya sendiri. Dengan kata lain, supaya bisa disebut sebagai parrhesiast, seorang individu harus memperlihatkan dalam dirinya suatu hubungan erat antara apa yang ia katakan dengan apa yang ia perbuat. Teori dan praktek selalu harus berjalan beriringan. Seseorang boleh berbicara secara meyakinkan, namun ia juga harus bertindak dan berlaku benar dan baik.
\end{abstract}

Kata-kata kunci: Foucault, parrhesia, intelektual, subyek, etika.

Abstract: The paper presents one of Foucault's many pregnant technical

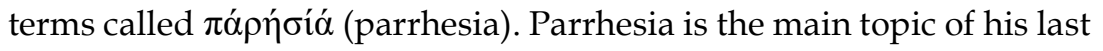
seminar delivered at the University of California in Berkeley, USA, entitled "Discourse on Truth: The Problematization of Parrhesia." These series

* Konrad Kebung, Sekolah Tinggi Filsafat Teologi Ledalero, Maumere, Flores, Nusa Tenggara Timur. E-mail:konradkebungsvd@gmail.com. 
of seminar and the issue of sexuality as discussed in his History of Sexuality vol. 2 and 3, added with all his lectures and interviews during the last two years before his death, are seen as the peak of his three axes of thought, namely the axis of subjectivity and ethics. There, we see how humanbeing is aware of him/her self as subject of him/her own self or of being the subject of ethics. This means that the invididual, based on his freedom and maturity, is practically able to relate with him/her self (rapport a soi). He is then to be called the parrhesiast, who not only tells the truth to other people, but also be able to tell the truth to him/her self. In other words, in order to be a parrhesiast, an individual should show in his/her life a correspondence between what he/she speaks and what he/she does. Theory and practice should go hand in hand. One can speak convincingly, yet is also to behave well.

Keywords: Foucault, parrhesia, intellectual, subject, ethics.

\section{PENDAHULUAN}

Michel Foucault (1926-1984) adalah salah seorang filsuf terkemuka abad ke-20 dari Perancis yang memiliki nama besar dalam dunia filsafat. Sebagai seorang intelektual, namanya selalu disandingkan dengan filsuf eksistensialis atheis Prancis, Jean-Paul Sartre (1905-1980). Dalam rentang waktu hidup yang singkat, Foucault menghasilkan banyak karya tulis, yang menjadikan dia sebagai pemikir dunia yang terkenal. Karena ketenaran namanya itu, dia diundang sebagai dosen tamu di banyak negara besar, di mana tradisi filsafat sangat kuat. Dia memiliki banyak rencana dan proyek kerja ke depan dengan sejumlah penerbitan baru, namun karena kematian menjemputnya lebih awal dalam usia 57 tahun, maka beberapa karya yang telah direncanakan tidak dapat diterbitkan. Pada hari-hari menjelang kematian, dia masih aktif memimpin banyak seminar, kuliah, dan interview, yang pada umumnya berbicara mengenai subyektivitas dan kesadaran manusia sebagai subyek etika. Di situ dia banyak berbicara mengenai parrhesia, seksualitas dan seni membangun diri (stilisasi diri) yang dia sebut estetika eksistensi. 


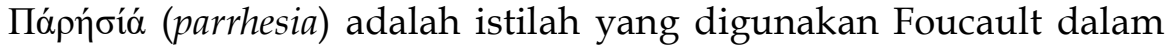
seminar terakhirnya di Universitas California di Berkeley, CA, pada bulan Oktober dan Nopember 1983. Seminar ini kemudian dihimpun dan dicatat oleh Joseph Pearson dalam "Discourse and Truth: The Problematization of Parrhesia." ${ }^{1}$ Diskusi tentang parrhesia dan seksualitas, dilengkapi dengan kuliah-kuliah terakhir Foucault di College de Françe tentang pembentukan diri dan seni mengatur hidup pribadi, merupakan proyek terakhir Foucault ketika ia berbicara mengenai subyek atau etika. Semua diskusi mengenai pembentukan diri ini pada umumnya diambil dari praktek-praktek dan pengalaman hidup pada zaman YunaniRomawi klasik. Lewat semua praktek diri itu Foucault mau melihat subyek yang berhubungan dengan dirinya sendiri lewat diskursusnya mengenai parrhesia dan seksualitas.

\section{ARTI KATA PARRHESIA}

Kalau Immanuel Kant bertanya "Apa itu Pencerahan" (What is Enlightenment?), Foucault justru bertanya “Apa itu masa kini kita?" Mungkinkah ruang masa kini dapat ditemukan dalam pelbagai pengalaman masa lalu kita? Pertanyaan-pertanyaan seperti ini tidak berhubungan dengan analisis kebenaran, melainkan suatu penelitian tentang ontologi masa kini atau ontologi tentang diri kita sendiri. Menurut Foucault, hal ini berarti bahwa setiap orang yang mengatakan kebenaran harus berurusan dengan masa kini, dan bukannya masa lampau. Foucault coba meyakinkan pembacanya untuk berpikir secara lain dan selalu mencoba berbicara tentang masa kini. ${ }^{2}$ Untuk suatu diskusi yang lebih bermakna tentang mengatakan kebenaran, Foucault membawa pembacanya kepada gagasan Yunani klasik tentang parrhesia sebagai titik tolak, dan meneliti bagaimana hal ini dilihat sebagai suatu ontologi masa kini dan ontologi tentang diri kita sendiri.

1 Transkrip seminar ini kemudian dibukukan dengan judul Michel Foucault: Fearless Speech, ed. Joseph Pearson (Los Angeles: Semiotext(e), 2001.

2 Lih. Miguel Morey, “On Michel Foucault's Philosophical Style,” dalam Michel Foucault: Philosopher, terj. Timothy J. Armstrong (New York: Routledge, 1992), pp. 117-128. 
Jauh sebelum kata parrhesia ini didiskusikan secara filosofis dan ilmiah, orang-orang Yunani sudah mempraktekkannya dalam hidup mereka. Bahkan parrhesia ini dilihat sebagai salah satu unsur penting dalam nilai-nilai budaya mereka. Terminologi teknis ini baru digunakan dalam teks-teks sastra sekitar abad 5 SM, dalam tragedi-tragedi Euripides (sekitar tahun 484 - 407). Istilah ini juga banyak ditemukan dalam teksteks patristik yang ditulis pada akhir abad 4 dan selama abad $5 \mathrm{M}$, terutama oleh Johanes Chrisostomus (345 - $407 \mathrm{M}) .^{3}$ Istilah ini juga secara intensif digunakan oleh Foucault dalam seminar dan kuliah-kuliahnya yang terakhir.

Kata parrhesia berasal dari kata bahasa Yunani "pan" yang berarti semua dan "rhesis" atau "rhema" yang berarti ekspresi, apa yang dikatakan, pidato atau perkataan. Kata ini juga berarti ketrampilan berbicara, kehalusan, keterbukaan, keterusterangan, dan kebebasan berbicara. Dalam arti riil parrhesia berarti aktivitas untuk mengungkapkan segala sesuatu yang ada dalam pikiran seseorang (action de tout declarer, tout exprimer). Dengan demikian kata ini juga mengandung kemerdekaan dan kebebasan menggunakan bahasa. Karena itu parrhesia berarti kemerdekaan berbicara, keterbukaan mengungkapkan sesuatu, berbicara dengan penuh keyakinan, berbicara secara terbuka dan polos. ${ }^{4}$

Dalam bahasa Yunani, kata yang syarat makna ini memiliki tiga bentuk pengungkapan, yaitu parrhesia yang digunakan dalam bentuk nominal, yang berarti menceritakan kebenaran, berbicara secara jujur dan sopan (franc-parler atau free speech). Kata kerja parrhesiazomai atau parrhesiazesthai berarti menggunakan parrhesia, dan parrhesiastes yang berarti orang yang menggunakan parrhesia atau parrhesiast (orang yang berbicara tentang kebenaran). Kata yang terakhir ini jarang digunakan,

3 Lih. Joseph Pearson, p. 11. Bdk. Konrad Kebung, Michel Foucault: Parrhesia dan Persoalan mengenai Etika (Jakarta: Obor, 1997), hlm. 10. Lihat juga Pierre Miguel, "parrhesia” dalam Dictionaire de Spiritualité, vol.12 (Paris: Beausesne, 1983), pp. 260-261; juga A Greek-English Lexicon, yang disusun oleh H. Liddel \& R. Scott (Oxford: Clarendon Press, 1966), p. 1344. Bdk. Heinrich Schlier, "Parrhesia and Parrhesiazomai" dalam Theological Dictionary of the New Testament, Vol.5, pp. 871-886.

4 Konrad Kebung, hlm. 10. 
namun kadang-kadang juga ditemukan dalam teks-teks klasik. Dari definisi etimologis ini kita dapat menemukan beberapa arti kata parrhesia yang diterima secara umum pada zaman Yunani klasik dan yang didiskusikan dalam seri seminar ini.

Pertama, parrhesia berarti kebebasan berbicara. Parrhesia selalu dihubungkan dengan kepolosan dan kejujuran mengungkapkan apa yang ada dalam pikiran dan hati. Pembicara tidak menyembunyikan apa-apa, melainkan membuka seluruh pikiran dan isi hatinya kepada orang lain. Dia ingin memberi kejelasan bahwa apa yang dia katakan sesungguhnya keluar dari hatinya, dan ini merupakan pendapatnya sendiri. Karena itu si parrhesiast selalu menggunakan ungkapanungkapan yang langsung sebagai lawan dari ungkapan-ungkapan retorik. ${ }^{5}$

Kedua, parrhesia selalu digunakan dalam hubungan dengan kebenaran. Dalam hampir semua teks klasik, parrhesia selalu memiliki arti positif, yaitu berbicara tentang atau mengatakan kebenaran. Pembicara mengatakan apa yang benar karena ia tahu bahwa apa yang dia katakan adalah benar. Si parrhesiast sama sekali tidak bimbang akan kebenaran yang ia ungkapkan. Pengungkapan kebenaran ini mengandaikan kualitas moral yang dibutuhkan, yakni pertama, ia mengetahui kebenaran dan kedua, ia mampu meneruskan kebenaran ini kepada orang lain. Namun parrhesia juga mengandung arti negatif atau pejoratif, suatu istilah yang hampir sama dengan "chattering" yang berarti berbicara banyak tapi mengatakan sedikit atau tidak ada arti. Ini berarti berbicara yang tidak distingtif tanpa kualifikasi. ${ }^{6}$

Ketiga, parrhesia dan bahaya. Dalam menyampaikan kebenaran, seorang parrhesiast selalu berhadapan dengan risiko dan bahaya.

5 Konrad Kebung, hlm. 11. Juga Joseph Pearson, p. 12

6 Chattering merupakan salah satu ciri utama konstitusi demokratik yang tidak baik, dalam mana setiap warga memiliki hak dan kebebasan untuk berbicara dan mengungkapkan segala sesuatu, walaupun itu berakibat fatal dan berbahaya untuk negara. Lihat Republic dari Plato (577b), Phaedrus, 240e, dan The Laws, 649b dan 671b. 
Karena itu ia harus memiliki suatu sikap yang berani. Keberanian menyampaikan kebenaran ini terlihat jelas dalam The Bacchae, salah satu tragedi Euripides. Semua orang tahu bahwa orang-orang yang membawa berita buruk kepada raja akan dihukum dan yang membawa kabar baik akan diganjari. Dalam drama atau tragedi itu, dikisahkan bahwa hamba Pentheus membawa berita buruk tentang kebobrokan yang dilakukan oleh Maenads dalam komunitas, dan melaporkan ini kepada raja di istana. Pentheus dengan gagah berani menyampaikan berita ini kepada raja dan berusaha meyakinkan sang raja untuk menggunakan parrhesia dengan harapan bahwa ia tidak dihukum karena berita ini. Sebaliknya ia dipuji oleh sang raja sendiri. ${ }^{7}$ Dalam kebiasaan Yunani klasik, risiko seorang parrhesiastik tidak hanya risiko hidup dan mati. Menegur teman dan mengatakan kepadanya bahwa perbuatannya adalah salah dan tidak benar juga merupakan risiko dalam persahabatan. Di sini parrhesiast masuk dalam kritik, karena parrhesia juga mengandung arti memberikan nasihat kepada seseorang bagaimana ia harus bertindak, atau menegur orang karena tingkahnya salah. Parrhesia juga bisa dilihat sebagai kritik atas tingkah laku atau sikap pribadi sendiri, karena dengan menegur orang lain, penegur sudah memiliki pola tertentu bagaimana ia seharusnya bertindak dan berlaku secara tepat — kritik terhadap orang lain dan kritik terhadap diri sendiri.

Keempat, parrhesia dilihat sebagai tugas atau kewajiban. Menyampaikan kebenaran dilihat sebagai tugas dan kewajiban, dan ini tergantung pada keharusan moral seorang parrhesiast. Seorang parrhesiast tidak pernah merasa dipaksa atau terpaksa menyampaikan kebenaran. Paksaan atau merasa terpaksa menghentikan predikat sebagai seorang parrhesiast. Menyampaikan kebenaran harus dilihat sebagai tugas dan kebajikan yang sungguh mencerminkan kebebasan dan kesadaran akan

7 Michel Foucault: "Discourse on Truth: The Problematization of Parrhesia” (seterusnya digunakan singkatan PP), p. 15. Kaum Maenads adalah para wanita saleh yang dengan kaki telanjang berlari-lari dan bersikap ganjil dalam kota. Lihat Euripides, The Bacchae, 666-667; bdk Euripides, The Complete Greek Tragedies, vol 4, ed. David Green dan R. Lattimore (Chicago: University of Chicago Press, 1974), p. 572. 
tugas personal seorang parrhesiast. Berikut ini adalah kata-kata Foucault sendiri mengenai parrhesia:

Parrhesia adalah suatu aktivitas verbal dalam mana pembicara memiliki suatu relasi khusus dengan kebenaran melalui kepolosan dan kejujuran, suatu relasi tertentu dengan hidupnya sendiri lewat risiko dan bahaya, suatu relasi dengan diri sendiri atau orang lain melalui kritik [kritik terhadap diri dan terhadap orang lain] dan suatu relasi khusus dengan hukum moral melalui kebebasan dan kebajikan. Atau lebih tepat dikatakan: parrhesia adalah aktivitas verbal, dalam mana pembicara mengungkapkan relasi personalnya dengan kebenaran dan siap menanggung risiko karena ia sadar bahwa menyampaikan kebenaran merupakan suatu tugas untuk menolong orang lain atau diri sendiri. Dalam parrhesia pembicara menggunakan kebebasannya dan lebih memilih kejujuran daripada persuasi, kebenaran dari pada kepalsuan atau sikap diam, risiko mati daripada hidup dan rasa aman, kritik daripada kebohongan, dan kebajikan moral daripada kepentingan diri dan apathi moral. ${ }^{8}$

\section{PERKEMBANGAN MAKNA DAN PRAKTEK PARRHESIA}

Parrhesia, yang ditulis dalam banyak teks klasik dan memiliki makna dalam kehidupan masyarakat Yunani klasik, merupakan cerminan dari apa yang sudah dipraktekkan dan dihidupkan dalam kebudayaan Yunani klasik. Foucault justru mau melihat beberapa aspek penting dalam kaitan dengan parrhesia yang ada dalam kebudayaan Yunani klasik sejak abad 5 SM hingga awal abad Masehi, ketika mulai muncul ajaran Kristen. Foucault melihat ada tiga pandangan utama yang berkembang waktu itu antara lain, pertama, adanya hubungan problematis antara parrhesia dengan retorika. Dalam tradisi Sokratik-Platonik, parrhesia dipertentangkan dengan retorika. Menurut Plato, retorika merupakan karya artistik atau fiktif yang berada dalam lingkup dunia rupa yang memiliki sifat yang berubah-ubah. Karena itu retorika dan semua karya tragik dan artistik dilihat sebagai fotokopi atau bayangan

8 PP, pp. 7-8; Bdk. Kebung, hlm. 13 dan Pearson, p. 19. 
dari dunia yang riil, inteligibel, bersifat permanen, dan tidak berubahubah. Justru karena itu retorika dianggap rendah. ${ }^{9}$

Sudah dikatakan di atas bahwa dalam parrhesia pembicara mengatakan dengan tegas bahwa apa yang dia katakan merupakan pendapatnya sendiri, dan ini berarti ia tahu apa yang mau ia katakan sesuai dengan keyakinannya sendiri. Sebaliknya retorika menyiapkan bagi pem-bicara aparatus teknis dalam usaha meyakinkan pendengarnya. Karena itu dalam retorika pembicara sangat tergantung pada pandangan dan pendapat orang lain. Juga retorika kerap menggunakan kalimat-kalimat yang panjang dan bersambung, sedangkan dialog, yang melalui pertanyaan dan jawaban, merupakan ciri khas parrhesia. Dialog dengan itu dilihat sebagai teknik utama dalam relasi parrhesiastik. ${ }^{10}$

Oposisi parrhesia dan retorika juga ditemukan dalam Phaedrus. Di sini Plato melihat perbedaan antara logos yang berbicara tentang kebenaran dan logos yang tidak mampu menggunakan parrhesia. Di sana Plato mengklaim bahwa pembicara harus tahu tentang kebenaran supaya mampu berbicara tentangnya. Misalnya dalam Seneca, pembicaraan-pembicaraan personal dilihat sebagai model-model terbaik untuk berbicara secara jujur dan mengatakan kebenaran, namun ini juga dapat diperkaya oleh hiasan-hiasan retorik. Selalu saja ada usaha untuk memadukan parrhesia dengan retorika dalam karya para ahli retorika pada awal masa kekuasaan Romawi. Namun oposisi ini masih sangat kuat sampai sekitar abad 2 Masehi dan bahkan masih berlangsung selama berabad-abad.

Kedua, Foucault juga mengarahkan perhatiannya secara khusus kepada diskusi tentang kaitan antara parrhesia dengan politik. Dramadrama yang ditulis Euripides menunjukkan bahwa parrhesia adalah ciri khas dan esensial dari demokrasi Athena. Demokrasi Athena dilihat sebagai konstitusi (politeia), dalam mana setiap warga menikmati demo-

9 Lihat diskusi Plato tentang seni dalam Republic, $\mathrm{X}$.

10 Lih. Pearson, pp. 20-21. M. Foucault, PP, p. 8. Oposisi ini juga dapat dilihat dalam dialog Gorgias (461e, 487a-e, 491e). 
krasi (demokratia), kesamaan hak dalam berbicara (isegoria), adanya pengakuan atas hak dan hukum yang sama bagi semua warga negara (isonomia), dan parrhesia. Namun, kemudian dalam monarki Helenistik, makna politis ini berubah. Parrhesia dipusatkan pada hubungan antara para penguasa dengan para penasihat atau orang-orang dalam lingkungannya. Tugas para penasihat ialah menggunakan parrhesia untuk menolong raja dalam membuat pertimbangan dan mengambil keputusan, dan mencegahnya dari segala macam penyalagunaan kuasa. Seorang pemimpin akan menjadi seorang tiran apabila ia tidak lagi menghargai para penasihatnya. ${ }^{11}$

Ketiga, analisis Foucault mengenai relasi antara parrhesia dengan filsafat. Filsafat di sini haruslah dilihat sebagai suatu seni hidup (techne tou biou). Ia melihat peran yang dimainkan Sokrates sebagai seorang parrhesiast sejati dan filsuf yang pernah berkata: "Saya tidak pernah berhenti mempraktekkan filsafat dan mengajak anda sekalian, dan siap menjelaskan makna kebenaran kepada siapa saja yang saya jumpai..."12 Di sini Foucault melihat Sokrates sebagai seorang filsuf dan parrhesiast. Dalam Alcibiades Maior, parrhesia filosofis dikaitkan secara erat dengan tema perhatian terhadap diri sendiri (care of the self atau epimeleia heauton).

Ketiga pandangan utama di atas, yakni kaitan antara parrhesia dengan retorika, parrhesia dengan politik dan parrhesia dengan filsafat, terlihat sangat jelas dalam karya-karya Euripides, yang disajikan dalam kuliah Foucault yang kedua pada tanggal 31 Oktober 1983. Melalui suatu studi yang mendalam tentang tragedi-tragedi Euripides, Foucault masuk ke dalam suatu studi yang intensip tentang literatur Yunani dan menemukan di mana dan bagaimana pola-pola relasi parrhesiastik dipraktekkan dalam interaksi sosial. Ini semua dapat dilihat dalam sekian banyak tragedi Euripides seperti The Phoenician Women, Hippolytus, The

11 J. Pearson, p. 22; Konrad Kebung, hlm. 15.

12 Lih. Apology, 29de dalam Plato: The Collected Dialogues, ed. Edith Hamilton dan Huntington Cairns (Princeton: Princeton University Press, 1989 (cet.14), pp. 15-16. 
Bacchae, Electra, Ion, dan Orestes..$^{13}$ Dalam semua drama atau tragedi ini kita bisa melihat arti dan makna yang berbeda dari kata parrhesia. Semua drama ini menunjukkan pelbagai macam pola dan relasi parrhesiastik. Pada umumnya drama-drama ini memperlihatkan parrhesia politis, filosofis dan personal. Drama-drama ini juga dilihat sebagai sumber informasi yang baik dan cukup lengkap tentang siapa yang disebut parrhesiast, bagaimana mereka menggunakan parrhesia, dan apa syarat-syarat untuk menjadi parrhesiast, juga bahaya dan risikorisiko dari parrhesia. ${ }^{14}$

Baru dalam tragedi Orestes untuk pertama kali muncul arti negatif (peyoratif) dari parrhesia sebagai lawan dari arti positif yang dikemukakan dalam pentasan-pentasan awal. Parrhesia negatif ini mengundang pertanyaan seperti, siapa yang harus menggunakan parrhesia negatif ini? Apakah cukup hanya menerima parrhesia sebagai suatu hak sipil yang memungkinkan setiap warga untuk menggunakan kebebasan berbicara dalam negara? Atau apakah parrhesia hanya boleh diberikan kepada warga negara tertentu menurut status sosial atau kebajikankebajikan personal mereka? Di sini terlihat jelas jurang antara sistem egalitarian yang memungkinkan setiap warga untuk menggunakan parrhesia dan keharusan memilih orang-orang tertentu untuk menggunakan parrhesia sedemikian rupa demi kebaikan negara dan warganya. ${ }^{15}$

Dalam studi-studi yang intensip tentang sejarah Yunani klasik, Foucault melihat bahwa parrhesia menjadi semakin problematis sejalan dengan berkembangnya demokrasi Athena. Demokrasi dibentuk oleh politeia, yaitu konstitusi dalamnya semua warga hidup di bawah hukum yang sama (isonomia), memiliki kesamaan hak dalam pemerintahan, dan memiliki hak-hak berbicara yang sama (isegoria). Yang menjadi persoalan ialah bahwa isonomia dan isegoria ini diakui oleh konstitusi Athena, sedangkan parrhesia tidak. Juga parrhesia tidak dijabarkan secara jelas

13 J. Pearson, pp. 25-74; Konrad Kebung, hlm.15-25.

14 Konrad Kebung, hlm. xi.

15 Konrad Kebung, hlm. xi. Bdk. PP, p. 46. 
dalam term-term institusional. Pada waktu yang sama institusi demokratik seperti ini harus juga memberikan tempat yang sama bagi semua bentuk parrhesia, padahal seorang parrhesiast bisa juga adalah warga negara yang tidak baik, yang mungkin bisa mendatangkan bahaya untuk kota atau negara, dan dengan demikian akan menghancurkan kehidupan demokratik. Pertanyaan ialah: Siapakah yang akan berbicara tentang kebenaran dalam batas-batas sistem institusional kalau setiap orang memiliki hak yang sama untuk berpendapat? Demokrasi tidak mampu menentukan siapakah yang memiliki hak atau kualitas-kualitas khusus untuk berbicara tentang kebenaran. Di sini Foucault memperlihatkan antinomi Yunani antara parrhesia (kebebasan bicara) dan demokrasi. Demokrasi memungkinkan kemerdekaan berbicara namun ini selalu dibatasi oleh hukum dan konstitusi.

Foucault juga menunjukkan antinomi ini dalam teks-teks klasik. Salah satu teks yang sangat terkenal terungkap dalam Republic (557ab). Di sana Sokrates menyebut beberapa bahaya yang mungkin dari institusi-institusi demokratik. Namun isu yang paling penting di sana ialah bahwa kemerdekaan berbicara menjadi semakin erat dikaitkan dengan pilihan eksistensi (choice of existence). Di sana parrhesia lebih dilihat sebagai sikap personal yang sangat penting dalam kehidupan politis di kota. Lewat teks-teks ini juga dapat dilihat karakter moral dan etis dari seorang parrhesiast. Ini juga terlihat jelas dalam karya Aristoteles, Nicomachean Ethics (1124b28).

Perlu diketahui bahwa sebelum demokrasi Athena dilembagakan, struktur kuasa aristokratik sudah sangat kuat. Tentu saja sistem ini tidak dengan gampang menerima suatu sistem baru atas nama demokrasi. Inilah alasan munculnya sekian banyak kritik dalam epok sejarah waktu itu ketika demokrasi mulai berkembang di Athena. Foucault menunjukkan di sini beberapa teks klasik yang ditulis untuk mengeritik praktekpraktek demokrasi dalam kehidupan politis masyarakat Athena.

Isocrates, dalam orasinya "On the Peace" (peri eirenes), mempertentangkan sikap orang Athena dalam urusan-urusan pribadi dan pela- 
yanan masyarakat. Ia mengatakan bahwa apabila mereka menghadapi kesulitan dalam urusan-urusan pribadi, mereka akan mencari seorang penasihat dengan latar belakang pendidikan yang tinggi untuk menyelesaikan masalah mereka. Namun apabila mereka menghadapi masalah dalam urusan negara, mereka tidak mau menerima orang-orang pandai dan trampil ini. Dalam hal ini mereka mungkin akan bersahabat dengan orang-orang yang tidak benar dan menghindarkan diri dari orang bijaksana dan terhormat. Orang seperti ini tidak pernah akan berkorban demi kepentingan umum. ${ }^{16}$ Isocrates juga menambahkan bahwa orang-orang Athena hanya mendengarkan para orator yang tidak laku dan tidak ingin mendengarkan pembicara-pembicara yang baik, karena para orator itu cenderung hanya mengatakan apa yang orang ingin dengar. Orator seperti ini disebut Isocrates sebagai pembual (flatterer). Sebaliknya, orator yang baik dan terhormat memiliki keberanian untuk menantang masyarakat. Mereka mampu mengritik, mendidik dan mentransformasikan kehendak masyarakat demi kepentingan negara. Pertentangan antara kehendak masyarakat dan kepentingan negara adalah persoalan utama yang menjadi kritik Isocrates terhadap institusi demokrasi Athena. ${ }^{17}$

Dalam Aeropagiticus (355 SM), Isocrates membuat perbandingan antara demokrasi lama di bawah konstitusi Solon dan Cleisthenia dengan demokrasi Athena terakhir yang ia sebut sebagai demokrasi lemah dan yang mengalami banyak kemerosotan. Isocrates memuji demokrasi lama karena di sana orang sungguh sadar akan tugas dan peran mereka dalam kota (demokratia), kebebasan (eleutheria), kebahagiaan (eudemonia), dan kesamaan hak dalam hukum (isonomia). Sebaliknya, dalam demokrasi yang lemah orang kurang mengendalikan diri (akolasia), kebebasan tanpa hukum (paranomia), kebahagiaan diartikan sebagai kebebasan untuk melakukan apa saja yang mereka inginkan, dan kesamaan dalam hukum telah menjadi parrhesia. ${ }^{18}$ Dalam konteks ini parrhesia hanya memiliki arti negatif. Dalam situasi ini Isocrates menegaskan bahwa

$16 P P$, p. 51.

17 PP, p. 52.

18. PP, p. 52. 
tidak mungkin orang menikmati kehidupan demokratis sekaligus parrhesia (dalam arti positif).

Plato, dalam Republic (557a-b), menunjukkan suatu teks yang menjelaskan pandangan Sokrates tentang awal mula dan perkembangan demokrasi. Sokrates mengklaim:

...demokrasi muncul apabila kaum miskin menang dan menyisihkan atau menghapus partai lain, dan masyarakat diberi bagian yang sama sebagai warga, juga mendapat hak untuk dapat mengambil jabatanjabatan dalam negara - dan para petugas ini dipilih dan diangkat oleh warga negara. ${ }^{19}$

Karakter dasar demokrasi adalah kebebasan. Setiap orang memiliki kebebasan berbicara dan dapat melakukan apa saja yang dia inginkan. Plato dengan ini tidak mempersalahkan parrhesia karena membuka kemungkinan yang luas bagi orang untuk mempengaruhi kota. Plato justru menekankan bahaya utama parrhesia, yakni bahwa ia nanti akan menjerumuskan orang ke dalam keputusan yang tidak baik atau mempersiapkan sarana bagi para pemimpin kota untuk menjadi korup dan tiran. Bagi Plato, amat berbahaya apabila setiap orang memiliki kebebasan berbicara dan berbuat sesuai dengan keinginannya, maka kita akan temukan macam-macam cara, pola dan praktek hidup. Situasi ini dapat memunculkan sekian banyak kota otonom dengan konstitusi dan hukum-hukumnya sendiri. Kalau ini terjadi maka sudah terjadi anarki yang melingkupi kebebasan memilih pola hidup sendiri tanpa batas.

Foucault melihat secara khusus dua aspek utama yang selalu diperhitungkan pada abad keempat. Teks-teks Plato menunjukkan bahwa kebebasan berbicara semakin dihubungkan dengan pilihan eksistensi atau pilihan pola hidup pribadi. Parrhesia di sini lebih dilihat sebagai sikap atau kualitas personal dan sekaligus menjadi satu kewajiban utama bagi kehidupan politik kota, atau bisa menjadi bahaya untuk kota dalam kaitan dengan parrhesia peyoratif. ${ }^{20}$

19 Edith Hamilton and Huntington Cairns, ed., Plato: The Collected Dialogues, p. 785.

20 PP, p. 55. 
Dalam institusi-institusi monarkis, kebebasan berbicara digunakan terhadap raja. Di sini parrhesia lebih banyak tergantung pada kualitas personal raja dan penasihatnya. Namun orang juga bisa menemukan bahwa parrhesia lebih dilihat sebagai sikap personal daripada suatu privilese institusional, sebagaimana dipraktekkan dalam sebuah kota demokratis. Transformasi ini jelas terlihat dalam teks-teks Aristoteles. Aristoteles menggunakan beberapa kali kata parrhesia dalam karyakaryanya. Namun konsepnya tentang istilah ini tidak memiliki referensi apa pun dalam institusi politis. Sebaliknya kata ini digunakan secara eksklusif dalam kaitan dengan monarki atau sebagai gambaran personal dari karakter moral dan etis. ${ }^{21}$

Parrhesia kemudian berkembang menjadi semakin personal dan melingkupi kualitas-kualitas moral. Atas dasar ini, Foucault memulai diskusinya mengenai relasi antara parrhesia dan pengaturan atau perhatian terhadap diri (care of the self).

\section{PARRHESIA DAN CARE OF THE SELF}

Parrhesia dan Care of the Self, bagian terakhir dari seminar Foucault, terdiri dari tiga kuliah terakhir yang merupakan bagian terpenting dari seminar, tetapi juga merupakan klimaks dari seluruh karya filosofis Foucault. Sebagaimana diketahui bahwa Foucault membagi seluruh karyanya atas tiga bagian besar sesuai dengan poros atau tema yang dia emban. Poros-poros berpikir itu adalah pengetahuan, kuasa, dan subyek atau etika. Poros pengetahuan dapat dilihat dalam seluruh karya awal, di mana Foucault, sebagai ahli sejarah sistem-sistem berpikir, membuat analisis tentang kaitan antara yang normal dengan yang tidak normal, yang sakit dan sehat, yang dapat berpikir dan tidak dapat berpikir (raison et deraison). Semuanya ini didiskusikan dalam tema

21. Aristoteles, Nicomachean Ethics (NE), 1124b28-9 dan 1165a29. Di sini parrhesia adalah kebebasan berbicara dan bertindak secara terbuka. Juga karyanya Politics, 1313b15, di mana parrhesia berhubungan dengan menyampaikan apa yang ada dalam pikiran; juga dalam Rhetoric, 1382b20, di mana parrhesia berarti keterbukaan berbicara. Referensi utama adalah The Basic Works of Aristotle, ed. Richard McKeon (New York: Random House [t.t], cet, ke 13). 
kegilaan (madness), dan bagaimana si sakit melihat dirinya dipertentangkan dengan orang sehat, bagaimana orang normal memunculkan istilah tidak normal, bagaimana penanganannya dari era sejarah yang satu ke era sejarah yang lain, hingga munculnya pelbagai cara penanganan yang lebih bagus dan manusiawi sesuai dengan cara berpikir manusia dalam tiap era sejarah. Orang-orang yang dicap sebagai sakit dan gila sungguh diobjektifikasi oleh orang-orang yang sehat dan normal. Namun model-model penanganan terhadap mereka memunculkan banyak institusi baru dengan rupa-rupa model pelayanan, bahkan lewat cara-cara ini muncul banyak macam ilmu pengetahuan baru di mana selain manusia dijadikan objek, ia juga menyadari diri sebagai subyek ilmu tertentu. Dalam seluruh karya awal, dia menggunakan metode arkeologi dengan menggali informasi lewat studi-studi arsip dan pelbagai pengalaman manusia pada masa lalu.

Poros berpikir kedua adalah kuasa. Analisis tentang kuasa baru diintensifkan mulai tahun 1975 dengan terbitnya Discipline and Punish dan The History of Sexuality 1, yang terbit pada tahun 1976. Dengan menggunakan metode genealogi (diwariskan dari Genealogy of Moralnya Nietzsche), ia membuat analisis tentang kuasa yang berfokus pada isu kriminalitas dan penjara, dan seksualitas. Foucault membuat analisis tentang praktek kuasa sejak zaman Ranaisance sampai abad 17 dan 18 terhadap isu kriminal (penjara) dan seksualitas. Di sana para narapidana sungguh menyadari diri sebagai objek dari institusi yang menangani mereka, tapi mereka juga mesti berkembang menuju kesadaran diri mereka sebagai subyek yang juga punya kuasa dalam relasi mereka dengan orang lain, termasuk para pengawas penjara. Diskusi-diskusi tentang seksualitas juga akhirnya terarah kepada kesadaran manusia sebagai subyek dari seksualita dan etika. Dalam diskusi tentang seksualitas, manusia justru sadar akan dirinya sebagai yang memiliki keinginan dan nafsu serta kenikmatan-kenikmatan yang adalah asasi dan yang harus dia akui. Dan di sana dia sadar bahwa dia sungguh merupakan subyek yang berhadapan dengan dirinya sendiri. Dengan demikian Foucault masuk ke dalam poros ketiga yang merupakan klimaks dari seluruh karyanya, yaitu pembentukan diri lewat care of the self. 
Pokok terakhir yang dianalisis Foucault dalam kaitan dengan care of the self adalah wacana tentang seksualitas dan parrhesia. Di sini saya lebih memperhatikan isu parrhesia sebagai langkah menuju relasi subyek dengan dirinya dalam stilisasi diri dan care of the self.

Di atas telah dilihat analisis Foucault tentang penggunaan kata parrhesia dalam teks-teks Yunani klasik dan praktek parrhesia sepanjang sejarah Yunani klasik. Dalam analisis tentang hubungan antara parrhesia dengan care of the self, Foucault secara tajam dan mendetail melihat praktek-praktek parrhesia yang bersifat personal yang dia lihat dalam diri Sokrates sebagai seorang parrhesiast. Dalam diri Sokrates, Foucault melihat seorang parrhesiast dan filsuf. Khusus dalam buku Laches, Sokrates sungguh tampil sebagai seorang parrhesiast yang tidak hanya mengantar patner bicaranya menuju suatu pilihan hidup, tetapi ia juga membawa parrhesia masuk ke dalam relasi-relasi personal. Sokrates menunjukkan ini lewat hidupnya sendiri, di mana ada kecocokan antara kata-kata (logos) dengan hidup (bios). Parrhesia Sokratik ini sungguh melibatkan relasi antara logos, kebenaran dan hidup, dan relasi ini sungguh bersifat personal. Dalam Laches juga terlihat jelas bahwa parrhesia haruslah digunakan untuk meyakinkan seseorang bahwa dia harus memperhatikan dirinya dan juga orang lain (care for others). Ini mengandaikan bahwa orang harus bisa mengubah hidupnya sendiri. ${ }^{22}$

Selain menjelaskan parrhesia Sokratik, Foucault juga mengembangkan praktek-praktek parrhesia sambil memusatkan perhatian pada relasi antara kebenaran dengan diri (self) dan diri dengan orang lain. Di sini "praktek" harus dimengerti dalam dua arti yaitu, penggunaan parrhesia dalam relasi antarmanusia atas cara yang khusus, dan teknikteknik yang digunakan dalam relasi seperti ini.

Sebagai suatu aktivitas, parrhesia dapat digunakan paling kurang dalam tiga macam relasi antarmanusia, yaitu hidup bersama dalam komunitas, hidup bermasyarakat, dan relasi personal antarmanusia. ${ }^{23}$

22 Konrad Kebung, hlm. xiii, 30-31.

23 Konrad Kebung, hlm. 29-43. Juga J. Pearson, pp. 107-142. 


\section{Parrhesia dan Hidup Komunitas}

Kaum Epikurean yang kerap berbicara tentang persahabatan, sangat menekankan hidup komunitas lebih dari semua filsuf zamannya. Demikian juga beberapa kelompok Stoik dan para filsuf Cynik, juga para penasihat moral dan politis bagi kaum aristokratik. Secara khusus Foucault menyebut Epictetus, seorang dari kelompok Stoik, yang sudah mulai berdiskusi tentang "berbicara secara terbuka dan jujur." Kendati sangat sedikit diketahui tentang kehidupan Epictetus, namun gagasangagasannya ditemukan dalam banyak teks klasik. Selain itu, sekolah Epikurean juga mengenal dua cara mengajar, dan karena itu juga dua tipe pengajar atau guru. Cara pertama menggunakan metode mimbar yang tidak terlalu dihargai dan dinilai tinggi. Guru-guru demikian juga tidak dinilai tinggi. Cara kedua adalah interviu personal. Ini dilihat sebagai cara mengajar yang bagus, dan guru yang mengajar selalu diberi tempat terhormat. Perbedaan ini menunjukkan suatu relasi pedagogis antara guru dengan murid. Dengan ini jelas bahwa dalam sekolah Epikurean, lewat interviu personal, guru menolong murid-murid untuk menemukan kebenaran tentang diri mereka dan bukan hanya berbicara tentang kebenaran kepada orang lain yang bersifat sangat otoritarian.

Dalam kaitan dengan ini juga dikenal metode kebidanan (mauetika techne) dalam dialog Sokratik. Dalam metode ini Sokrates, sebagai guru, tampil sebagai bidan yang coba lewat pertanyaan-pertanyaan dan penjelasan, mengumpan patner bicara untuk mengungkapkan apa yang terkandung dalam otak atau pikirannya. Sokrates sangat yakin bahwa patner bicaranya juga memiliki pengetahuan dan pencerapan dari dunia pengalamannya. Lewat metode ini patner bicara tidak hanya dapat menemukan kebenaran tentang dirinya, yaitu relasi pribadinya dengan logos, tetapi juga bahwa partner bicaranya memperoleh banyak pengetahuan lain tentang dunia ide-ide, kodrat jiwa, dan lain sebagainya.

\section{Parrhesia dan Hidup Publik}

Parrhesia sebagai aktivitas yang tampak dalam kehidupan publik dipraktekkan oleh kelompok Cynik. Para filsuf ini berhubungan erat 
dengan Sokrates melalui Diogenes dan Antisthenes, pendiri aliran Cynisisme. ${ }^{24}$ Gagasan dasar kaum Cynik adalah bahwa cara hidup seseorang dapat menjadi tanda atau gambaran dalam relasi pribadinya dengan kebenaran. Dengan demikian nilai tertinggi diberikan kepada cara hidup pribadi seseorang. Kita harus menjadi guru bagi diri kita sendiri (autarkeia). Bagi kaum Cynik, mengurus diri sendiri dan hidup yang tidak bergantung pada orang dilihat sebagai syarat mutlak dalam kebahagiaan manusia. Penekanan pada pola hidup seperti ini dengannya menghapus segala macam kebergantungan yang ada dalam kebudayaan. Sikap radikal ini menolak segala macam masyarakat, peradaban, hukum, pendapat atau institusi sosial, sejauh mereka menghalangi kebebasan dan ketakbergantungan seseorang. Bagi kelompok ini, kebenaran yang terungkap dalam cara hidup seperti ini harus diketahui dan diikuti orang lain, dan oleh karena itu ia harus diwartakan sekian rupa sehingga dapat diterima dengan mudah. Juga karena ini merupakan suatu cara hidup publik, maka ia harus dilihat dan besifat provokatif serta menarik bagi orang lain. Inilah alasan mengapa kaum Cynik menyukai kotbah atau pewartaan kritis dan dialog-dialog provokatif sebagai praktek-praktek parrhesiastik. Karena itu mereka suka berbicara di depan banyak orang, di panggung teater, juga dalam perayaan-perayaan di mana berhimpun banyak orang. Di sini jelas bahwa cara hidup mereka menarik orang lain, karena hidup mereka sendiri harus merupakan petunjuk kebenaran dan dengan demikian banyak orang lain akan mengikuti mereka.

Dialog provokatif juga dapat dilihat dalam "Fourth Discourse on Kingship," karya Dio Chrysostom dari Prusa. Di sana diperlihatkan dialog provokatif antara Diogenes dan Alexander Agung. Diogenes, sebagai seorang filsuf, adalah lambang corak hidup yang bebas, selfsufficient, dan dilengkapi dengan kebajikan moral naturalistik. Dia juga adalah lambang parrhesiast sejati yang sederhana, gembira, bahagia

24 Cynisisme muncul sekitar dua abad setelah meninggalnya Sokrates. Mulai dari akhir abad 1 SM sampai abad $4 \mathrm{M}$ aliran ini berkembang pesat dengan banyak anggota. Nama ini berasal dari kata bahasa Yunani kynikoi yang berarti seperti anjing. Karena itu Diogenes kerap dipanggil anjing (Rhetorica, buku III, bab 10, 1411a24). Lih. Konrad Kebung, hlm. 33-36. 
dan bukannya seorang pembual. Sebaliknya, Alexander sangat masyur sebagai pemimpin negara dan militer dengan sekian banyak kali menaklukkan musuh dalam peperangan, bahkan ingin menaklukkan dunia dengan kekuataan dan kuasanya. Dalam dialog dengan Diogenes, kendati kerap merasa terluka, Alexander masih senang mendengar permainan parrhesiastik Diogenes. Sebagai hasil, ia memperoleh banyak jawaban yang ingin ia temukan, seperti hal yang sangat indah di dunia ini ialah kebebasan berbicara, sebagai lawan dari penipuan dan bualan. ${ }^{25}$

Memang dialog provokatif ini sangat berbeda dengan dialog Sokratik. Dalam permainan parrhesiastik Cynik, Alexander cenderung untuk bertanya dan Diogenes harus menjawab. Ini sungguh berbeda dari apa yang kita temukan dalam dialog Sokratik. Lebih dari itu kalau Sokrates lebih banyak bermain dengan ketidaktahuan patner bicaranya, Diogenes sungguh bermaksud untuk mengusik kesombongan Alexander. Dalam dialog Sokratik, betapapun kerap patner bicara merasa sakit hati, tujuan utama ialah agar ia menyadari ketidaktahuannya, dan dengan itu ia mengakui bahwa ia tidak tahu apa-apa tentang apa yang dia anggap sudah tahu. Sokrates mau menunjukkan kepada patner bicara-nya bahwa ia sebenarnya tidak tahu tentang ketidaktahuannya. Dalam kasus Diogenes, lewat serangannya terhadap kesombongan Alexander, Alexander dibawa ke batas kontrak parrhesiastik pertama, yaitu setuju untuk meneruskan permainan dan memilih untuk terlibat dalam diskusi.

Bagi Foucault, pertemuan agresif antara Diogenes dan Alexander membuka suatu pergulatan antara dua macam kuasa: kuasa politis dan kuasa kebenaran. Di sana sang parrhesiast menerima dan siap menghadapi suatu bahaya permanen. Akibat utama dari pergulatan parrhesiastik dengan kuasa bukannya untuk membawa patner bicara kepada suatu kebenaran baru, atau kepada suatu level baru kesadaran diri, melainkan untuk memungkinkan dia menginternalisasi pergulatan parrhesiatik ini, untuk bergulat dalam dirinya melawan kesalahannya 
sendiri, dan untuk berada bersama dirinya dalam cara sperti Diogenes ada bersamanya. ${ }^{26}$

Lewat kaum Cynik, kita melihat sesuatu yang baru dan berbeda dari segala macam wacana yang pernah dibicarakan para filsuf sebelumnya. Dalam tradisi Platonik, Aristotelian dan Stoik, para filsuf lebih banyak membuat referensi pada doktrin, teks, dan prinsip-prinsip teoretis lain untuk pengembangan filsafat mereka. Dalam tradisi Epikurean, para pengikut Epikurus membuat referensi pada suatu doktrin dan pada contoh pribadi dari Epikurus sendiri sebagai pedoman bagi para pengikutnya. Namun dalam tradisi Cynik, referensi utama filsafat ialah contoh hidup sendiri. Tidak ada teks dan doktrin baku. Bagi kaum Cynik, seorang filsuf harus menjadi tokoh panutan dan harus bersifat ksatria.

\section{Parrhesia dan Hidup Personal}

Parrhesia juga diakui sebagai aktivitas dalam konteks relasi personal individual. Di sini Foucault banyak mengutip teks-teks dari Plutarchus dan Galen untuk menjelaskan permainan parrhesiastik dalam kerangka relasi personal, dan bagaimana orang berhubungan dengan dirinya melalui kebenaran. Dalam salah satu teks mengenai parrhesia, Plutarchus berusaha menjawabi pertanyaan bagaimana kita mengenal seorang parrhesiast atau membedakan orang ini dari pembual. ${ }^{27}$ Semua jawaban Plutarchus menyiapkan beberapa pokok utama yang menjadi pertimbangan kita. Ia mengklaim bahwa dalam kehidupan pribadinya, setiap orang memerlukan sahabat yang berperan sebagai truth-teller. Juga dalam diri manusia, ada suatu relasi predominan, yaitu relasi "cinta diri" (philautia), yang menjadi dasar ilusi tentang siapakah kita ini. Cinta diri inilah yang membuat kita sebagai pembual terbesar bagi diri kita. ${ }^{28}$ Pembual selalu berlawanan dengan maksim "kenalilah dirimu," dan untuk membebaskan diri dari cinta diri kita perlu seorang truth-teller.

26 Konrad Kebung, hlm. 35.

27 PP, p. 89. Teks Plutarchus: "How to tell a Flatterer from a Friend" (52a-b), terj. F.C.Babbitte, dalam Moralia, I, pp. 261-395).

28 PP, p. 89. 
Persoalan utama sekarang bagaimana membedakan kriteria seorang truth-teller dengan seorang pembual? Plutarchus memperlihatkan dua kriteria utama: pertama, harus ada kecocokan antara apa yang dia katakan dengan tingkah laku dan perbuatannya sendiri. Kedua, ia juga harus memiliki suatu kepastian, kemantapan dan kestabilan dalam pilihan, pendapat, dan buah pikirannya.

Untuk mengenal seorang parrhesiast sejati, Galen (130-200M) coba menjawabi pertanyaan di atas dengan mengatakan bahwa bila orang ingin membebaskan diri dari keinginan pribadi, ia membutuhkan seorang parrhesiast. Ingat bahwa ingat diri adalah akar dari semua khayalan dan tipu diri. ${ }^{29}$ Teks-teks Galen menunjukkan bahwa parrhesiast tidak perlu mesti seorang sahabat atau seseorang yang anda kenal. Namun dalam tradisi Plutarchus, Seneca dan Sokrates, seorang parrhesiast seharusnya berasal dari kalangan sahabat. Ia tidak membenci, tetapi juga tidak mencintai anda. Anda juga dapat memilih dia sesuai dengan keinginan anda. Namun bagaimanapun juga harus ada suatu kriterium: anda seharusnya pernah mendengar tentangnya, bahwa ia memiliki reputasi baik, cukup tua dan barangkali lebih kaya dari anda sendiri. Karena apabila ia lebih miskin dari anda, kemungkinan lebih besar bahwa ia dapat menipu dan memperdayai anda. ${ }^{30}$ Galen juga menegaskan bahwa parrhesiast tidak perlu seorang berpendidikan tinggi dengan gelar doktor atau dokter. Yang paling penting ialah kalau ia mampu memperlihatkan kebenaran dalam dirinya sendiri.

\section{PARRHESIA DAN ASKESE}

Dalam hubungan dengan askese, parrhesia selalu dilihat sebagai aktivitas dalam konteks relasi-relasi individual dan personal. Secara khusus Foucault menunjukkan bagaimana seseorang mengemban relasi dengan dirinya sendiri lewat teknik meditasi dan introspeksi yang dilihat

29 Konrad Kebung., hlm. 38; Lihat Galen, “The Diagnosis and Cure of the Soul's Passion”, terj. Paul W. Harkins, pp. 31-33. Bdk. Pearson, p. 138.

30 Lih. Michel Foucault, Histoire de la sexualité 3: Le souci de soi (Paris: Gallimard, 1984), p. 72; Terj. Inggris, The History of Sexualituy 3: The Care of the Self, oleh Robert Hurley (New York: Pantheon Books, 1986), pp. 68-69. 
sebagai sarana dalam usaha menerima diri sendiri. Lewat penelitianpenelitian khusus tentang teknik-teknik yang digunakan dalam literatur filsafat dan moral pada dua abad pertama Masehi, Foucault melihat bahwa ada pergeseran relasi parrhesiastik dari penekanan pada keberanian menceritakan kebenaran kepada orang lain menuju keberanian untuk membuka kebenaran tentang diri sendiri. Ia mengatakan bahwa kebenaran yang langsung menghadang seseorang membutuhkan suatu askese yang terdiri dari banyak latihan praktis. Di sini askese dilihat sebagai suatu teknik hidup yang menuntut latihan yang terus menerus. Secara umum latihan-latihan itu dikenal dengan nama "pemeriksaan batin" (examination of conscience). Penelitian ini memperlihatkan perbedaan antara teknik-teknik latihan, bagaimana latihan-latihan yang berbeda ini mencerminkan aspek-aspek akal, perasaan, dan tingkahlaku. Kendatipun latihan-latihan ini bervariasi, semuanya mengandung hubungan antara kebenaran dengan diri sendiri.

Foucault membuat analisis tentang macam-macam teknik, antara lain, pertama, pemeriksaan batin secara pribadi. Dalam "De Ira" (On Anger), Seneca menunjukkan manfaat menilai akal kita sendiri. Pemeriksaan batin adalah sarana untuk melatih akal dan menghentikan kemarahan; kesempatan orang melihat kedalaman diri dan berdialog dengan diri sendiri. Orang menjadi inspektor bagi diri mereka sendiri (speculator sui). Praktek seperti ini merupakan tuntutan dalam tradisi Pythagorean yang selalu dibuat sebelum tidur. ${ }^{31}$ Latihan ini juga dilihat sebagai suatu kritik diri demi bertindak lebih baik lagi pada masa yang akan datang. ${ }^{32}$

Kedua, latihan untuk mendiagnose diri. Untuk teknik membuat diagnose diri, Foucault mengambil teks Seneca tentang stabilitas atau ketenteraman batin (De Tranquillitate Animi). Stabilitas batin merupakan suatu perasaan yang menyenangkan yang memiliki akar dalam penguasaan dan pemilikan diri. Teks ini berkisah tentang Serenus, penjaga malam Kaiser Nero, yang merasa tidak tentram dan aman. Ia tidak mam-

31 PP, p. 98; Lih. M. Foucault, Le souci de soi, p. 77.

32 J. Pearson, pp. 145-150. 
pu mengatasi dirinya dan karena itu dia tidak stabil. Dalam keadaan tidak stabil ini dia datang kepada Seneca memohon bantuan. Serenus dalam konsultasi ini menyampaikan bahwa dalam pemeriksaan batin, ia sadar bahwa ada sikap jeleknya yang belum dapat ditemukan, ada yang masih cukup tersembunyi, dan ada yang kadang-kadang bisa mencuat keluar. Ia juga merasa bahwa ia belum bebas dari hal-hal yang ia takuti dan yang ia tidak suka. Ia merasa tidak sakit, tapi juga tidak sehat.

Teks-teks Serenus terdiri dari tiga bagian utama yaitu, bagian pertama berbicara tentang kehidupan pribadi dan rumah tangganya sendiri, yaitu bagaimana ia melihat kekayaan dan miliknya sendiri. Kelihatan di sana bahwa Serenus tidak memiliki banyak kebutuhan dan tidak melekatkan diri pada materi. Bagian kedua berbicara mengenai kehidupannya di tengah masyarakat. Juga jelas bahwa dia tidak memiliki ambisi untuk memperoleh karier besar dalam kehidupan politis. Yang ia inginkan ialah agar dia bisa melayani orang lain. Bagian terakhir berbicara tentang kebal mati dan hidup setelah mati. Dalam teks-teks ini, Serenus lebih suka menggunakan kata-kata yang syarat makna dan bukannya hanya membual atau apa yang disebutnya retorika mengawang. Dari semua informasi ini jelas bahwa Serenus adalah seorang baik. Walaupun ia kerap merasa tidak tenang oleh pikiran-pikiran yang mengganggu, merasa tidak aman, namun semua ini justru menggerakkan dia untuk berkonsultasi dengan Seneca. Jawaban Seneca terhadap pemeriksaan batin dan permohonan moral ini merupakan suatu penelitian terhadap stabilitas akal dan pikiran. ${ }^{33}$

Ketiga, mentest diri sendiri. Untuk menjelaskan testing diri ini Foucault menggunakan teks "Discourse of Epictetus." Dikemukakan di sana banyak model pemeriksaan batin. Ada yang serupa dengan dua model pemeriksaan di atas, namun ada model pemeriksaan batin yang khas Epictetian adalah "testing diri," di mana seseorang berusaha untuk selalu menempatkan seluruh dirinya dalam cobaan. Teknik ini berkaitan

33 J. Pearson, pp. 150-160. 
erat dengan stabilitas akal. Lewat representasi yang senantiasa bergerak ke dalam diri, Epictetus harus belajar untuk membedakan representasi yang dapat ia kontrol dari yang tidak mampu ia kontrol, yang merangsang perasaan, emosi, dan tingkah laku. Untuk dapat menyelesaikan hal ini, orang harus mengambil sikap untuk selalu mawas diri terhadap segala representasinya, dan untuk menjelaskan semuanya ini, ia menggunakan dua metafor. Metafor pertama ialah penjaga malam atau pengawal pintu yang mengecek dan memeriksa identitas semua tamu yang mau masuk ke dalam rumah atau istana. Metafor kedua ialah penukar uang yang mengecek keaslian uang koin, memperhatikan, menimbang, dan lain-lain. Kedua metafor dan semua penjelasannya memiliki satu tujuan yakni supaya orang dapat menguasai dirinya, dan ini berarti dia berada dalam kondisi akal dan pikiran yang stabil. ${ }^{34}$

Secara singkat saya dapat membuat kesimpulan berikut ini. Pemeriksaan batin dan semua teks referensi menunjukkan suatu pergeseran besar dalam praktek parrhesiastik antara guru dengan murid. Kita lihat bahwa dalam periode, ketika parrhesia muncul dalam konteks bimbingan rohani, guru adalah orang yang menyingkapkan kebenaran kepada dan tentang murid. Dalam semua latihan itu guru menggunakan kata-kata yang polos dan jujur untuk menolong murid menyadari semua kesalahannya yang ia sendiri tidak lihat. Sekarang penggunaan parrhesia ditempatkan pada murid sendiri sebagai tugas dan kewajiban terhadap dirinya sendiri. Kebenaran dapat disingkapkan secara personal kepada dirinya atau juga kepada orang lain. Murid harus mengtes dirinya apakah ia mampu untuk menguasai dirinya sendiri.

Pada umumnya diakui bahwa orang dapat menjelaskan relasi personal dari pemahaman tentang diri sebagai yang melulu diperoleh dari maksim "kenalilah dirimu," sebagaimana ajakan Sokrates, katakata yang tertulis di pintu masuk kuil Delphi. Namun Foucault sendiri mengatakan bahwa belum cukup kalau kita hanya berhenti pada titik ini. Karena masih ada sekian banyak relasi yang tampak dalam pelbagai

34 J. Pearson, pp. 160-166. 
macam teknik yang mengambil bentuk latihan-latihan rohani. Ada latihan-latihan yang langsung berhubungan dengan perbuatan, ada yang menyangkut keseimbangan jiwa, ada yang mengenai aliran representasi, dan sebagainya. Yang paling penting di sini ialah relasi antara diri dengan kebenaran. Foucault mengklaim bahwa kebenaran diri melingkupi: pertama, suatu prinsip rasional yang didasarkan pada pernyataanpernyataan umum tentang dunia, hidup manusia, kebahagiaan, kebebasan, keharusan, dan sebagainya. Kedua, ia juga melingkupi hukumhukum praktis dalam tingkah laku dan perbuatan. Ia juga menegaskan bahwa latihan ini adalah bagian dari apa yang ia sebut aesthetic of the self. ${ }^{35}$ Ini dapat dibandingkan dengan peran seorang artis atau teknikus yang kerap harus berhenti sejenak dan memperlihatkan apa yang sedang ia kerjakan, mengingat kembali hukum atau aturan-aturan seni, dan membandingkan hukum-hukum ini dengan kemajuan yang tengah ia capai dalam karya seni ini.

\section{SIMPULAN}

Seminar "Problematisasi Parrhesia" ini bukan dimaksudkan untuk membahas persoalan kebenaran, melainkan persoalan penutur kebenaran (truth-teller), atau tentang truth-telling sebagai sebuah aktivitas. Karena itu, ini bukannya persoalan membuat analisis kriteria internal atau eksternal yang memungkinkan seorang Yunani atau Romawi atau siapa saja untuk mengenal apakah suatu pernyataan atau proposisi benar atau salah. Soal utama bagi Foucault adalah mau melihat truthtelling sebagai suatu aktivitas spesifik atau sebagai suatu peran. Namun dalam framework pertanyaan umum tentang peran penutur kebenaran dalam masyarakat, ada beberapa cara yang mungkin untuk membuat analisis. Misalnya, ia bisa membandingkan peran dan status truth-teller dalam masyarakat Yunani, Kristen atau non-Kristen - peran nabi, orakel, penyair, pakar, atau pengkotbah, sebagai truth-teller. Apa yang mau ia analisis ialah bagaimana peran truth-teller ini diproblematisasikan dalam filsafat Yunani. Lebih dari itu Foucault juga mau menunjukkan 
bahwa jika filsafat Yunani mengangkat persoalan kebenaran berdasarkan kriteria statemen atau penalaran yang benar, filsafat Yunani yang sama juga mengangkat soal dari sisi truth-telling sebagai sebuah aktivitas, yakni siapa yang mampu menyampaikan kebenaran? Apakah syaratsyarat moral, etis dan spiritual yang membuat seseorang dapat disebut sebagai truth-teller? Topik mana terasa penting untuk menyampaikan kebenaran (tentang dunia, alam, kota, tingkah laku atau tentang manusia)? Apakah konsekuensi menyampaikan kebenaran? Apakah akibat positipnya untuk kota, para pemimpin, atau individu-individu? Lalu apakah relasi antara truth-telling dengan pelaksanaan kuasa? Apakah truth-telling bisa disandingkan dengan pelaksanaan kuasa, atau apakah semua aktivitas ini harus bersifat independen dan terpisah? Apakah mereka harus dipisahkan atau apakah mereka saling mem-butuhkan? Jadi empat pertanyaan tentang truth-telling sebagai suatu aktivitas siapa yang mampu menyampaikan kebenaran, tentang apa, dengan konsekuesi apa, dan dengan relasi apa terhadap kuasa - tampak-nya menjadi persoalan-persoalan filosofis pada akhir abad 5 SM sekitar masa Sokrates, terutama lewat konfrontasinya dengan para Sophis tentang politik, retorika dan etika.

Menurut Foucault, problematisasi kebenaran mencirikan akhir filsafat Pra-Sokratik dan awal filsafat yang kita hidupi hingga sekarang. Karena itu problematisasi kebenaran ini punya dua sisi. Sisi pertama berurusan dengan penegasan bahwa proses menalar benar dalam menentukan apakah suatu pernyataan itu benar. Sisi yang lain berhubungan dengan pertanyaan: Apa pentingnya individu dan masyarakat untuk menyampaikan kebenaran, mengetahui kebenaran, atau mengenal orang-orang seperti itu? Untuk sisi pertama yang berurusan dengan karya akal dan nalar secara benar, kita punya akar pada tradisi besar filsafat di dunia Barat yang disebut analisis kebenaran. Sedangkan untuk sisi atau model kedua dikenal dengan nama tradisi kritis di dunia Barat. Di sini justru terdapat salah satu target Foucault dalam seminar ini ialah membentuk suatu genealogi tentang sikap kritis dalam filsafat Barat. 
Foucault menggunakan kata "problematzation" selama seminar ini, tapi tidak banyak memberikan penjelasan. Seperti kerap ia katakan bahwa apa yang ia ingin jelaskan dalam karyanya, bukan tentang sikap dan tingkahlaku orang pada masa lampau (mungkin masuk dalam bidang sejarah sosial), bukan juga tentang ide-ide dalam nilai-nilai representatif mereka. Ia justru mau membuat analisis tentang problematisasi, yang berarti, mengapa dan bagaimana hal-hal tertentu (sikap, fenomena, proses) menjadi suatu "masalah." Misalnya mengapa bentuk-bentuk perilaku dicirikan atau diklasifikasi sebagai kegilaan padahal bentukbentuk serupa yang lain sungguh diabaikan pada waktu-waktu historis tertentu. Hal yang sama juga dengan kejahatan dan kenakalan, juga problematisasi untuk seksualitas.

Analisis tentang parrhesia hanya dapat dimengerti secara tepat kalau ia ditempatkan dalam kerangka berpikir Foucault. Ini mau menegaskan bahwa gagasan parrhesia merupakan salah satu dari banyak diskusi penting Foucault tentang etika dan tingkahlaku individual, yang merupakan tema terakhir dari semua analisisnya. Parrhesia Foucault juga tidak dapat dipisahkan dari gagasannya tentang pengetahuan dan kuasa yang merupakan tema penting dalam karyanya. Jelas gagasannya tentang kuasa dan pengetahuan sungguh krusial untuk memahami parrhesia - dimengerti dalam kerangka relasi pribadi dengan kebenaran - karena kebenaran dimengerti sebagai pelaksanaan kuasa. Kebenaran dengan itu tidak berada di luar kuasa. Sebagaimana kuasa ditemukan di mana-mana, demikianpun pengetahuan dan kebenaran, dan di mana ada kuasa di sana ada pengetahuan dan kebenaran.

Dari seluruh karya Foucault yang berpuncak pada pembentukan subjek atau bagaimana subjek berelasi dengan dirinya, saya dapat mengatakan bahwa seluruh filsafat berpikir Foucault merupakan suatu teknologi diri. Cara berpikir ini justru mengantar kita kepada teknikteknik atau strategi-strategi subyek dibentuk. Parrhesia merupakan salah satu dari banyak gagasan yang diambil sebagai instrumen untuk menjelaskan praktek diri ini. Parrhesia jelas dilihat sebagai suatu strategi 
dalam formasi subyek. Ini yang disebut Foucault sebagai penguasaan diri (self-mastery). ${ }^{36}$

Di sini perlu disadari bahwa menurut Foucault konstitusi diri ini tidak dimengerti sebagai subyek yang secara sadar dan aktip membentuk dirinya, melainkan haruslah dilihat bagaimana subyek menjadikan dirinya sebagai obyek dalam usaha menguasai dirinya. Bagi Foucault subyek selalu merupakan representasi atau bayangan dan tidak pernah menjadi subyek secara utuh. ${ }^{37}$ Subyek ini dibentuk dalam praktekpraktek yang dapat dianalisis secara historis. Di sini ia mau menekankan bahwa bukan subyek yang membentuk dirinya, melainkan jaringan praktek, pengetahuan, teknik yang merupakan lapangan, dalamnya individu menjadi subyek.

Problematisasi parrhesia sungguh merupakan suatu perspektif kritis terhadap pola berpikir tradisional yang melulu didasarkan pada suatu kode yang telah dipersiapkan atau menerima begitu saja segala sesuatu tanpa pertanyaan. Ini adalah pandangan kritis tentang sejarah dan realitas hidup manusia. Di sini Foucault tidak hanya melihat sejarah dan realitas sebagai sesuatu yang terberi, tetapi ia juga menjadikan sejarah dan realitas hidup sebagai problem, dan mencoba untuk selalu merumuskan suatu jawaban khusus untuk setiap situasi. Karena itu problematisasi ini merupakan suatu kegiatan akal yang kreatif dan juga merupakan suatu etika berpikir.

Lebih dari itu, dalam kaitan dengan penguasaan diri, problematisasi parrhesia juga merupakan suatu perspektif kritis terhadap sikap dan pola tingkah laku seseorang. Foucault menunjukkan bahwa agar kita dapat menguasai diri kita, kita harus memiliki relasi khusus dengan kebenaran. Dalam kaitan dengan komunikasi dengan orang lain dalam hubungan dengan kebenaran, pertama-tama seseorang harus matang

36 Lih. Luther H. Martin, cs, (eds), Technologies of the Self: A Seminar with Michel Foucault (Amherst: The University of Massachusetts Press, 1988).

37 Lih. Charles Scott, The Question of Ethics: Nietzsche, Foucault, Heidegger (Bloomington: Indiana University Press, 1990), pp. 90-91. 
dalam dirinya agar ia mampu berbicara tentang kebenaran, meneruskan kebenaran ini, dan dapat memberi nasihat atau petunjuk bagi orang lain. Dengan kata lain, hidup seseorang seharusnya menjadi semacam truth-telling.

\section{DAFTAR RUJUKAN}

Aristoteles, Nicomachean Ethics, 1124b28-9 dan 1165a29.

Armstrong, Timothy (ed.and transl). Michel Foucault: Philosopher. New York: Routledge, 1992.

Euripides. The Completed Greek Tragedies, vol.4, ed.by David Green and R.Lattimore. Chicago: University of Chicago Press, 1974.

Hamilton, Edith and Huntington, Cairns. Plato: The Collected Dialogues. Princeton: Princeton University Press, 1989, cet.14.

Kebung, Konrad. Michel Foucault: Parrhesia dan Persoalan mengenai Etika. Jakarta: Obor, 1997.

Liddel, H. and Scott, R. A Greek-English Lexicon. Oxford: Clarendon Press, 1966.

Martin, H. Luther, cs (eds). Technologies of the Self: A Seminar with Michel Foucault. Amherst: The University of Massachusetts Press, 1988

McKeon, Richard, ed. The Basic Works of Aristotle. Random House [...] cet. 13 .

Miguel, Pierre, Dictionaire de Spiritualité, vol 12. Paris: Beausesne, 1983.

Morey, Miguel. “On Michel Foucault's Philosophical Style," dalam Michel Foucault: Philosopher. Ed by J. Armstrong. New York: Roudledge, 1922: 117-128.

Pearson, Joseph. Michel Foucault: Fearless Speech. Los Angeles: Semiotext(e), 2001.

Schlier, Heinrich. "Parrhesia and Parrhesiazomai" dalam Theological Dictionary of the New Testament, vol.5: 871-886.

Scott, Charles E. The Question of Ethics: Nietzsche, Foucault, Heidegger. Bloomington: Indiana University Press, 1990. 